particularly in plant and insect studies, observation of wildife and photography. The International Exchange Service received $1,129,476$ packages, weighing 767,399 lb. of government, scientific and literary publications, and distributed 63 full and 43 partial sets of United States official publications ; 85 copies of the Federal Register and 95 copies of the Congressional Record were also dispatched under the Interparliamentary Exchange of the Official Journal. The library received 52,669 publications during the year, bringing its holdings to 982,596 volumes, including 586,722 in the Smithsonian Deposit at the Library of Congress, and arranged 159 new exchanges. Eighty-one publications were issued during the year.

\title{
A CENTRAL INSTITUTE FOR SCIENTIFIC CINEMATOGRAPHY
}

$\mathrm{T}^{\mathrm{A}}$ find out what services a Central Institute for Scientific Cinematography could render to research and teaching in Great Britain, an inquiry has been carried out by the British Universities Film Council among a representative group of university teachers*.

A questionnaire relating to research was designed with the view of ascertaining, inter alia, whether by some method of sharing apparatus, existing facilities could be better used. The views of the research workers were as follows.

Research projects are undertaken with available resources in mind and unless cinematographic equipment already exists, or a grant to buy it is a possibility, cinematographic methods will not be used. Those departments with such equipment are using it most of the time and it is likely only to be available to visiting workers for short times; however, in the majority of instances visiting workers would be weleome, particularly to learn the methods in use. Many who use ciné equipment, and many more who do not do so at the moment, would welcome information concerning equipment available and the ways in which it can be applied to specific problems. This could be one of the functions of a Central Institute.

Another questionnaire was designed to determine how a Central Institute could assist teachers. The general reaction was that film at university level is properly used in showing the student moving phenomena which he cannot, for any reason, see at first hand ; film should not be used to show observations or experiments which the student should make himself. Many films available, although they fulfil this criterion, are unsatisfactory for university work because they include theoretical material best dealt with in other ways.

University teachers want short films to illustrate particular points which can be best illustrated by cinematographic methods. This need involves an automatic 'push button' projector which has yet to be perfected and a source of supply of the illustrations.

Until such time as apparatus and illustrations are forthcoming, films will have to be used as at present. Many teachers are not aware of the films available on their subjects; the multiplicity of catalogues and sources of supply, each of which has few, if any, items of university standard adds to this confusion. A more centralized source of information is essential.

While the foundation of a Central Institute which had sections for the making of research films, the loan of equipment and secondment of specialized staff, an

* The Use of Film in Teaching and Research in British Universities 1959. (A Report of an investigation carried out in selected University Departments by a Sub-committee: G. E. H. Foxon, G. H. Bell and C. J. Duncan.) Pp. 24, (Neweastle upon Tyne: C. J. Duncan, Hon. advisory service on research problems, the making of teaching films and a comprehensive information service on teaching films would appear one solution to these problems, it would seem that some of the current difficulties might also be solved in other ways. If there were greater recognition of the fact that, in many sciences, cinematographic methods have established themselves as a means of recording events for subsequent analysis, apparatus would be provided on a more liberal scale. Such apparatus requires skilled use, and short courses for training of technicians should be provided, perhaps in colleges of technology in various parts of Britain. If the research problems were tackled along these lines, it might be easier to obtain co-operation with other bodies interested in cinematographic methods in research and avoid the isolation which might result if a central institute for university research alone were set up.

The use of an existing organization for a comprehensive service of information of teaching film might well be considered. This would involve the organization in question receiving an earmarked grant from a government source, the grant being used for the collection, collation and dissemination of information on films available for instruction at university level.

Interest in the use of advanced cinematographic techniques is not confined to university departments ; other bodies such as the Research Councils, various Ministries and industry are also concerned. If it proposed to set up an Institute which served all these interests, the universities would make full use of the facilities provided. It may be envisaged that universities would, in particular, be users of an advisory service on the application of cinematographic methods and on technical problems, any short instructional courses on methods whether for scientists or their technicians, and an information service on existing film which could be used for further research or for teaching purposes. University departments might be users of a service for the loan of specialized apparatus although they would wish to be free to apply for grants for the provision of apparatus for their exclusive use as previously. Here there may be a difference between the needs of pure and applied science departments; the latter frequently undertake research of an ad hoc nature for which the availability of apparatus on loan might have distinct advantages in that it would encourage a high technical standard in the research film made; much film produced in research in Britain, although adequate for the immediate purpose of the worker, is seen to be of poor quality when shown at scientific meetings, and is also inadequate teaching material. 